\title{
Erratum to: Complex oscillation of meromorphic solutions for difference Riccati equation
}

Ye-Yang Jiang ${ }^{1 *}$, Zhi-Qiang Mao ${ }^{1}$ and Min Wen ${ }^{2}$

\section{"Correspondence:}

jyyang1018@126.com

'School of Mathematics and

Computer, Jiangxi Science and

Technology Normal University,

Nangchang, Jiangxi, China

Full list of author information is

available at the end of the article

\section{Erratum}

In the original published version of this article [1], the corresponding author's name was listed incorrectly as Yang-Yang Jiang. The correct name, as displayed in this article's author list, is Ye-Yang Jiang.

\section{Author details}

'School of Mathematics and Computer, Jiangxi Science and Technology Normal University, Nangchang, Jiangxi, China. ${ }^{2}$ Department of Civil and Architectural Engineering, Nanchang Institute of Technology, Nanchang, Jiangxi 330099, China. Received: 21 December 2014 Accepted: 22 December 2014 Published online: 16 January 2015

\section{References}

1. Jiang, Y-Y, Mao, Z-Q, Wen, M: Complex oscillation of meromorphic solutions for difference Riccati equation. Adv. Differ. Equ. 2014, 247 (2014)

\section{Springer}

Submit your manuscript to a SpringerOpen ${ }^{\circ}$ journal and benefit from:

- Convenient online submission

- Rigorous peer review

- Immediate publication on acceptance

Open access: articles freely available online

- High visibility within the field

- Retaining the copyright to your article

Submit your next manuscript at $\boldsymbol{s p r i n g e r o p e n . c o m ~}$

(c) 2015 Jiang et al: licensee Springer. This is an Open Access article distributed under the terms of the Creative Commons Attribution License (http://creativecommons.org/licenses/by/4.0), which permits unrestricted use, distribution, and reproduction in any medium, provided the original work is properly credited. 